\title{
Current situation and future prospects for beef cattle production in Indonesia - A review
}

\author{
Ali Agus ${ }^{1, a}$ and Tri Satya Mastuti Widi ${ }^{1, a, *}$
}

* Corresponding Author: Tri Satya Mastuti Widi Tel: +62-274-513363, Fax: +62-274-521578,

E-mail:widi.tsm@ugm.ac.id

'Faculty of Animal Science, Universitas Gadjah Mada, Yogyakarta 55281, Indonesia

a These authors contributed equally to this work.

ORCID

Tri Satya Mastuti Widi

https://orcid.org/0000-0003-4432-670X

Submitted Mar 21, 2018; Revised Apr 10, 2018; Accepted May 27, 2018

\begin{abstract}
Increasing demand in developing countries for animal sources of food including red meat is predicted to double by 2050. In Indonesia, there has always been a gap between supply and demand of beef with national beef production only satisfying about $45 \%$ of demand. This paper aims to describe the current features and prospects for beef production systems in Indonesia. The first part of the article reviews and analyses Indonesian beef cattle production systems. The second part addresses issues related to the current systems for beef production that could become important for future development of the beef industry in Indonesia. Recommendations to improve breeding and reproduction, to empower smallholder farmers, to improve the capacity of industry-related institutions to enhance technology transfer, and to develop systems for industry development such as integration of palm oil or plantations with beef cattle production are briefly discussed.
\end{abstract}

Keywords: Beef Cattle; Current Situation; Future Challenges; Indonesia; Production Systems

\section{INTRODUCTION}

Population growth, urbanization, economic progress and changing consumer preferences are boosting the demand for livestock products in developing countries [1]. Indonesia is an emerging economy, with high population growth and economic progress being the major driving forces for growing demand for animal sources of foods [2]. Red meat is a traditional animal food source in Indonesia [3]. With the majority of consumers being Muslim, beef and chicken are the most common meat proteins in Indonesia [4].

The cattle population in Indonesia is currently about 16.6 million head [5], of which 43\% is in Java Island, $25 \%$ is in the Eastern Islands, and the remaining 32\% is on other islands spread around Indonesia. Human population is expected to increase from the current 251 million to 274 million by 2020 . Average meat consumption is $2.72 \mathrm{~kg}$ per capita per year and is expected to increase to $3.36 \mathrm{~kg}$ per capita per year by 2020 [6]. Figure 1 shows projected beef demand in Indonesia from 2015-2024 [6]. Java has the highest production and consumption of beef, with $57 \%$ of the Indonesia's population living on this island [7]. In Indonesia, $90 \%$ of cattle production is from smallholder farming systems with about 6.5 million farmers living in the rural areas, and the remaining $10 \%$ is from more commercial farmers ( $<1 \%$ of all farmers) and large beef cattle companies whose target market is concentrated in Java island [8].

To date, there has always been a gap between supply and demand of beef. Domestic production can only satisfy about $45 \%$ of Indonesian demand for beef. The price of beef meat remains high and tends to increase year by year, as shown in Figure 2 [9]. To fulfil the demand for meat, the Indonesian Government has been importing meat and live feeder and slaughter cattle and some breeding stock. The high dependency on meat imports, partic- 


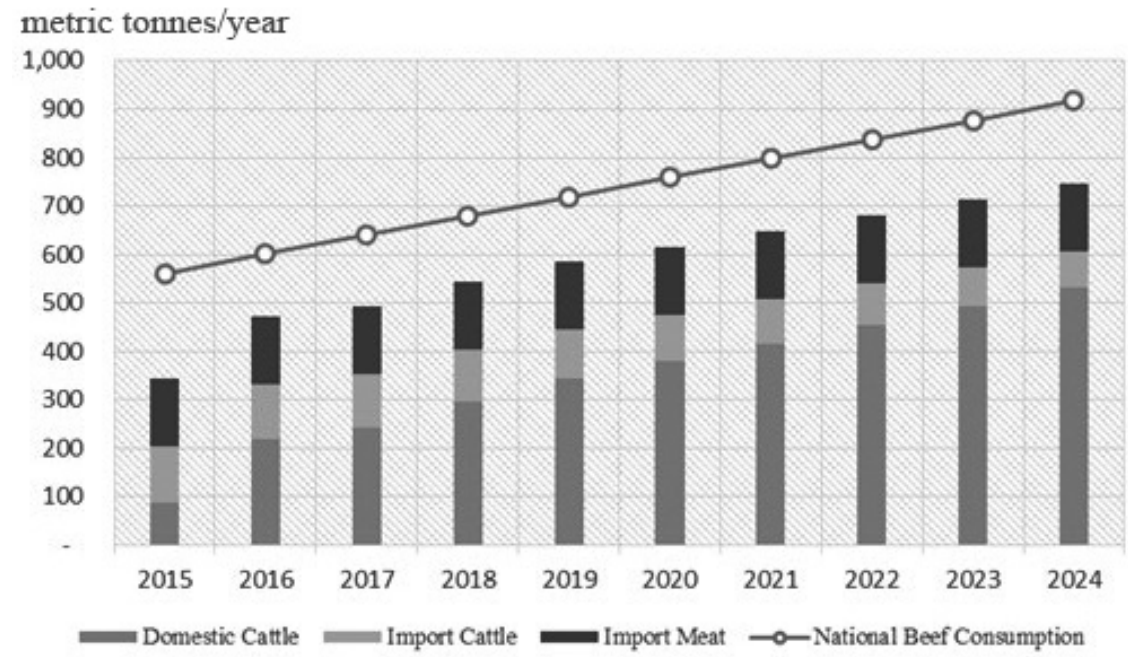

Figure 1. Beef supply and demand projection 2015 through 2024 (metric tonnes/yr) [6].

ularly from a single country, Australia, has becomes an issue of concern for Indonesian citizens. The import volume of cattle and beef meat is quite huge, while the export volume is very small (Table 1) [5]. As shown in Figure 1, the gap between supply and demand on beef will remain and may tend to increase. Hence, the Indonesian government has been developing a program since 2000 for meat self-sufficiency. However, this program is not yet effective in meeting the constantly increasing demand for beef, and a more serious effort is needed to reduce the gap between supply and demand for beef.

\section{CURRENT SITUATION FOR INDONESIAN BEEF CATTLE PRODUCTION}

For many years beef cattle have been an important part of Indonesian livelihood, especially for people who live in rural and agricultural areas [2,10]. In the early 1970s, live cattle were exported to Taiwan and Hong Kong. During the period from 1980 to present, beef cattle were considered a means of achieving self-sufficiency. A beef meat self-sufficiency program

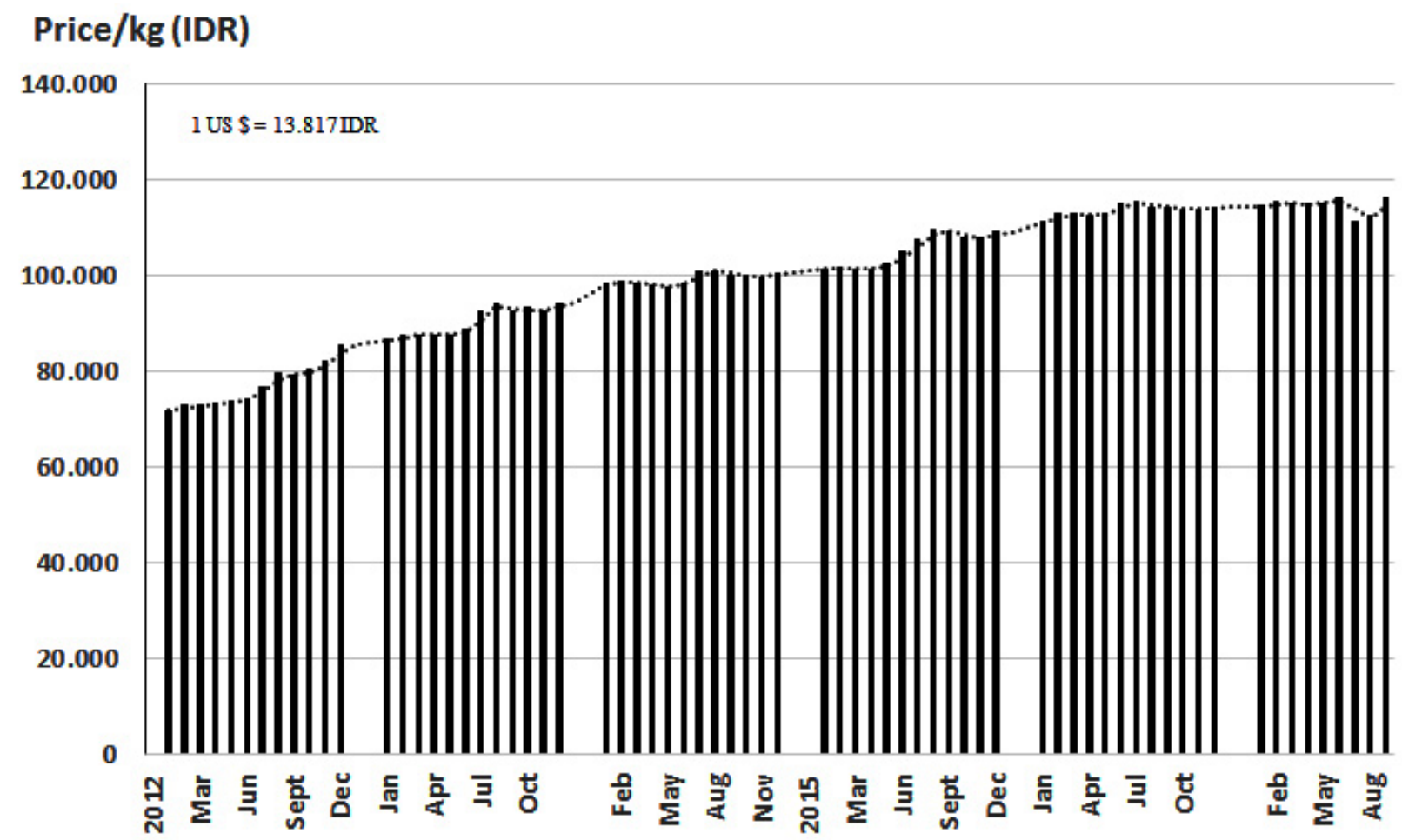

Figure 2. Beef meat price per kg in year 2012 through 2017 (IDR, Indonesian Rupiah) [9]. 
Table 1. Import and export of beef cattle and meat in year 2012 through 2016 $(\mathrm{kg})[5]$

\begin{tabular}{cccccc}
\hline \multirow{2}{*}{ Year } & \multicolumn{2}{c}{ Export } & & \multicolumn{2}{c}{ Import } \\
\cline { 2 - 3 } \cline { 5 - 6 } \cline { 5 - 6 } & Cattle & Beef meat & & Cattle & Beef meat \\
\hline 2012 & - & 1,676 & & $78,905,545$ & $34,878,404$ \\
2013 & - & 3,287 & & $120,021,422$ & $47,697,874$ \\
2014 & - & 2,609 & & $246,834,352$ & $76,887,337$ \\
2015 & - & 6,570 & & $197,764,113$ & $50,309,023$ \\
2016 & - & 14,841 & & $195,764,113$ & $116,761,381$ \\
\hline
\end{tabular}

(Program Swasembada Daging Sapi, PSDS 2001-2005) which was formally launched by government in 2001 , seemed to be unsuccessful, and the target was delayed until 3 times (moving target). The PSDS 2014 was the continuing program of PSDS 2001-2005 [11].

Commencing in 1990 until now, Indonesia has been importing live cattle including beef cattle, mainly from Australia. Intensive beef cattle feedlot production has developed since that time [6]. Beef cattle production can thus be classified into two major systems: smallholder farming systems, and intensive feedlot systems [6].

\section{Smallholder farming systems}

In Java Island, smallholder farmers are characterized by keeping between two and four head of cattle, coupled with integrating crop and livestock production and the use of stall feeding [2, 12,13]. While in other areas (i.e. Eastern Islands: Nusa Tenggara Barat, and Nusa Tenggara Timur), smallholder farmers may have more than 5 head, or over 50 head, since land is plentiful. These cattle are kept in extensive systems. The importance of livestock for smallholder livelihoods around the world is well understood [2]. For poor households the nonincome benefits of keeping livestock are particularly important [14]. In Indonesia, smallholder farmers do not only keep cattle to produce meat for the urban market, to support cropping with manure and draught power, but as livelihood assets as well [10]. The livelihood benefits of keeping cattle also include savings, buffering, insurance, and cultural benefits $[14,15]$. Cattle farming forms an important, but secondary, part of farmer occupations.

In both stall-feeding and extensive systems, the utilization of low quality feed, mainly from crop residues as well as agricultural by-products and other non-conventional feedstuffs is common practice. Crop residues (agricultural by products) that are considered as low-quality feeds are defined as less than $55 \%$ digestible and are deficient in true protein and with low levels of nitrogen and minerals [16,17]. Nevertheless, crop residues are abundant and inexpensive. The quality of most grasses in tropical regions are generally low with crude protein content $5.6 \%$ to $15.7 \%$, neutral detergent fiber content $45.2 \%$ to $85.4 \%$ [17]. One of the limitations of feed consumed by animals in the villages is a shortage of digestible energy. Therefore, supplementation is needed to be able to fulfil the requirement of animals for energy [17]. Most smallholder farmers only have a rudimentary knowledge of animal husbandry [8]. Many farmers are also of senior age with only an elementary level of education.

Most smallholder farmers keep breeding stock rather than fattening cattle, as they aim to have animals for longer period to provide progeny to be sold and a continuum of stock to provide manure for cropping [10]. The government has been encouraging the development of cattle breeding to build the national herd, but most of cattle breeders have low-input, lowoutput production systems which results in low beef production rates [8]. Consistent with this, as stated by [8], the nationwide beef cattle productivity in Indonesia is low because the of the low reproductive rate of cattle due to low fertility including low conception rates (56\%), long calving interval (18 to 21 months) and high calf mortality (5\% to $10 \%$ ) and low body condition score, resulting in slow growth of the national herd. In addition, farmers regularly sell productive females with about $10 \%$ to $30 \%$ being sold and slaughtered annually despite government regulation against the slaughter of productive females. This has further slowed the growth of the national herd, and all these factors are constraints to the development of domestic beef production in Indonesia.

In 2016, government launched a program called 'Sapi Indukan Wajib Bunting (UPSUS SIWAB)' which means a cow must be pregnant [18]. This program was addressed to increase cattle population, concerning in two mating systems, artificial insemination (AI) and natural mating [19]. Government set a target of 4 million head of productive female cattle would be inseminated and reach minimal $75 \%$ pregnancy rate or calving 3 million calves. To support SIWAB program, improvement of feeding was done by planting grasses and legumes on 13,000 ha land and providing water sources. To improve animal's health, medicines and vaccines were also provided [19]. Yet, the success of SIWAB program, in term of calving rate has not been achieved. Some sources reported by the end of 2017, 92.27\% from AI target was achieved while the calving rate was $54.13 \%$ from the set target [20].

Government programs on farmer's level, are usually addressed to increase domestic cattle population and beef meat production, and to improve economic condition of smallholder farmers [20]. However, unfortunately, the aforementioned programs were applied while the meat importation program is still running. One could consider that the government policies regarding meat sufficiency are contradicting each other to a certain degree and thus, are not as efficient.

Particularly in Java, since the 1980s the government has been promoting intensification of the beef cattle sector by introducing cross-breeding with high production potential breeds (Bos taurus, including European breeds) through AI. 
The favoured Bos taurus breeds for crossing with local Ongole cattle in Java are the Simmental and Limousine. Intensification, described by [21], as the increased use of external inputs and services to increase the output quantity and/or value per unit. Cross-breeding as tool for intensification has to be supported by better nutrition and management and requires a package of innovations on the basis of external inputs such as feed, health and breeding services, and credit and marketing [22]. However, in practice, cross-breeding has been limited to the provision of semen of exotic breeds. Consequently, cattle keeping systems have not become more efficient through crossbreeding [2]. Furthermore, the existence of the local Ongole cattle is threatened.

\section{Intensive feedlot systems}

In the early 1990's, feedlot businesses developed in response to the growing market for beef. Feedlot businesses are mostly located in areas near urban centres, particularly Jakarta, where the main bases for beef demand exist. As estimated by [8], about $75 \%$ of cattle imported from Australia into Indonesia are destined for feedlots, with a target intake weight of between 280 to $350 \mathrm{~kg}$ (average $320 \mathrm{~kg}$ ) live weight and an average daily gain of 1.5 to $2 \mathrm{~kg} / \mathrm{d}$ achievable. Australia also exports heavier finished cattle that are over $400 \mathrm{~kg}$ live weight to Indonesia, which are then sent directly to slaughter. Cattle that flourish in northern Australia include Brahman-crosses. Imports of these feeder cattle increased rapidly, by about $16 \%$ per annum from 2004 to 2008 [8].

Today, there are many feedlot businesses in West Java and Sumatra Island. In recent years there has been considerable investment into large-scale commercial feedlots and associated infrastructure such as feedlot facilities and dedicated transport ships to move live cattle from northern Australian ports to Indonesia [8].

The expense of purchasing feeder cattle and feed to finish cattle are the two largest variable costs for the feedlot industry in Indonesia. Use of agricultural and industrial by-products as the main feed resources is an important strategy for Indonesian feedlots to improve profitability. In Indonesia and in ASEAN countries in general the major agro-residues used as ruminant feed can be classified as: i) crop residues including rice straw, rice husk, sugar cane tops, corn stover, corn stalk, and soy bean hulls; ii) agro-industrial by products including cereal bran, coconut cake, palm kernel cake, soya bean meal, molasses, biofuel co-products such as distillers dried grains and soluble, pineapple waste, tapioca by product (onggok), and coffee seed pulp; iii) non-conventional feed resources, including a diverse range of feeds which, by definition, refer to those feeds not traditionally used in livestock feeding such as oil palm leaves, palm press fibre, cassava foliage, and other tuber foliage, sugar cane bagasse, cotton seed meal, rubber seed meal, cacao pod, fruit and vegetable wastes, aquatic plants such sea weed, and former foodstuffs [23].

A bottleneck which is sometimes faced by feedlot companies relates to unstable government policies. The government has been applying regulations for feedlot companies to import feeder cattle and female breeding stocks at a ratio of 5:1 within every period of feedloting (Permentan No. 02/Permentan/ PK 440/2/2017). This regulation creates difficulties for feedlot companies due to a shortage of resources including capital and land, especially on Java Island. Considering the limited housing capacity and capability of feedlot companies to keep $20 \%$ breeding stock of every single period of feedloting, we recommend keeping breeding stock as much as $20 \%$ of barn capacity. Government's support as lower interest rate (5\%) would be financially applicable.

\section{CATTLE AND BEEF VALUE CHAINS}

In Indonesia, the marketing system for beef-type cattle from smallholders is rather diverse and long with large numbers of different types of traders, as shown in Figure 3 [2]. These traders in the marketing system are important for smallholders, however, the traders may also cause concern as their costs can result in lower prices for producers [3].

The price of an animal is based on a live weight estimation by the local trader and the farmer. Feedlots and intermediate farmers mostly sell their cattle directly to buyers or butchers and the prices are determined based on measured live weight using weighing scales. Only a few cattle markets in Indonesia set prices based on live weight measurement using scales.

Cattle are slaughtered by local butchers in slaughter houses which are owned by government. Local butchers generally sell the meat in the regularly organized local markets [2]. Bakso (meat ball, which is a very popular food in Indonesia) sellers, households, small restaurants and small food processors are the buyers of meat in regular food markets or meat shops [24]. The demand for meat from large restaurants, hotels, and catering and food industries is met by local production from butchers and feedlots (65\%) and frozen meat imports (35\%) from Australia (Ahmadi, pers comm).

One of the problems which cause the beef cattle industry to grow slowly in Indonesia is the absence of government regulation to protect farmers from middle-man-traders. Although the cattle price in the market is high, the farmers get littie benefit from it, due to the farmer's poor bargaining position. Government regulation should cover activities from upstream (especially reproduction and feeding management, capital, small schemes of credit and institutions), to downstream (products and marketing). In agriculture-crop sector, government interventions are more in the form of subsidy (e.g. for seeds, fertilizers and tools) while massive-scaled programs are less. This way, crop-farmers have more autonomy in developing their farming system based on local resources and 


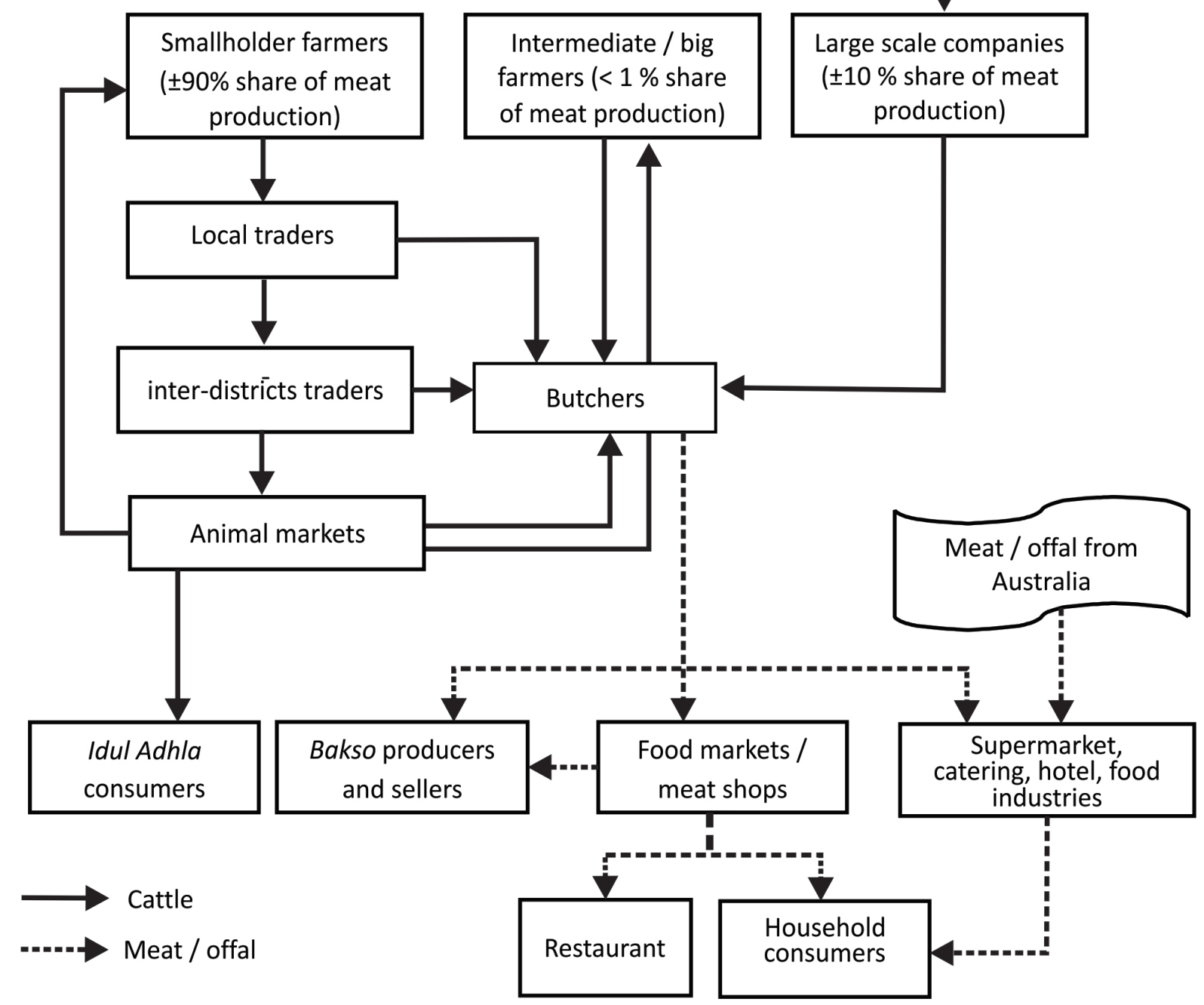

Figure 3. Value chain of cattle, meat, and offal in Indonesia [2].

characteristics. These methods could provide guidelines to be applied in livestock farming system with some adjustments, considering the variability of local resources and wisdom. Approaches to support the input production for animal farming should be in the interest of supporting small scale animal production.

\section{STRATEGIES AND FUTURE DIRECTIONS}

In relation to future issues and challenges, the Indonesian government is mainly concerned with meeting the increasing demand for meat by urban consumers, whereas smallholder farmers are mainly concerned with their livelihoods [2]. These different concerns have resulted in a gap in livestock production relative to demand, especially for cattle. The performance of beef cattle on smallholder farms needs improvement and some of the strategies proposed to address this issue are briefly discussed below.

\section{Breeding and reproduction}

Development and use of breeds adapted to tropical conditions is the first important step to achieve a sustainable breeding program. As a first step in development of sustainable breeding systems to provide suitable breeding stock, breeding institutions (government, private companies, and smallholder farmers) need to be revitalized and organized. Figure 4 shows an open nucleus breeding system suitable for use in Indonesia [6].

Government should be responsible for a national breeding system in Indonesia. When smallholder farmers take part in breeding programs, it should be within a Village Breeding 


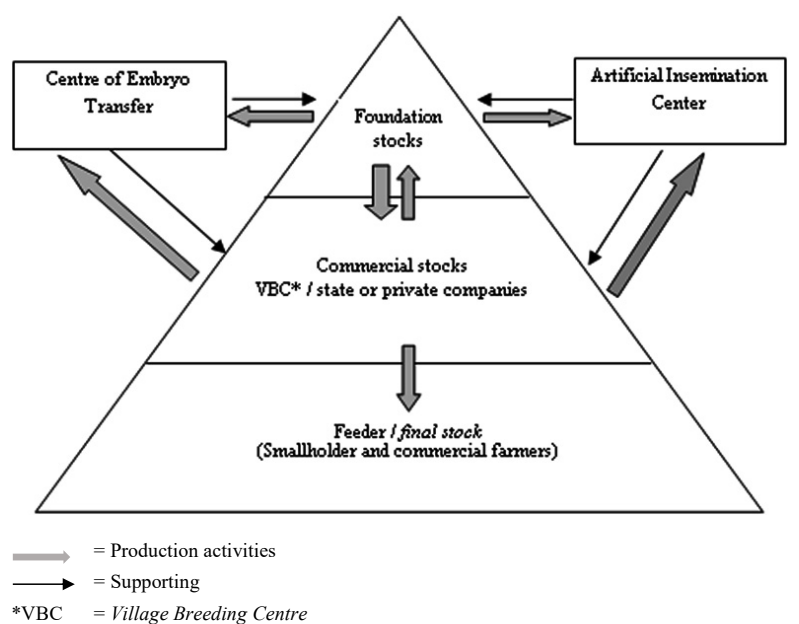

Figure 4. Open nucleus breeding system to produce breeding and feeder stocks [6].

Centre (VBC) scheme that government should control in terms of management, genetic selection, and recording. Concurrently, farmers need to improve their knowledge and skills in applying good breeding practices.

Currently, few private companies are interested in breeding activities due to the long turn-over period and high risk compared to feedlot activities. Government needs to provide facilities and incentives for private companies to undertake breeding programs. Improvement of access and land tenure is also needed, and integrated cattle breeding systems with plantations such as palm oil, is a promising option. Some pilot projects on smallholder farmers level and few private companies, have been successful through an extensive system under palm oil plantation and a semi intensive system utilizing oil-palm by products $[25,26]$. Unfortunately, most of big (private) palm-oil plantation industries avoid integrating cattle with palm oil plantation due to assumed problems related to manure that may be a growth medium for beetle and white rot fungi and trampled soils caused by cattle. However, none of the assumptions are scientifically proven.

\section{Empowerment of farmers}

Smallholder farmers are the most vulnerable stakeholder in the beef cattle production system. Smallholder farmers often have limited access to the inputs, information and services they require to grow a better future. They need to be continuously empowered in terms of input technologies, financial support, information, and markets.

A set of well-functioning formal rules is essential for the effective function of marketing systems. In many developing countries, the capacity of the state to conceive, implement and enforce such formal rules remains limited [27]. Integrated and synergistic approaches to empower farmers are required. Universities and/or research institutions should collaborate together to better enable knowledge and technology transfer to farmers. Applied and simple technologies that are useful and easy to adopt by the farmers are a priority. Feed technologies, byproduct technologies including compost management, and parasite control are among the simpler technologies required by farmers to improve cattle performance.

\section{Production systems and development}

The way livestock are managed and milk and meat are produced will be key factors for the future health of our planet. Animal agriculture is one of the most important components of global agriculture and livestock is one of the main users of the natural resource base [28]. Characteristics of animal agricultural systems have been developed in response to agro-ecological opportunities and demand for livestock commodities.

World livestock production systems are broadly classified into four main types [29], namely: i) Grassland-based systems, based solely on livestock; ii) Rain-fed mixed farming systems; iii) Irrigated mixed farming system; and iv) Landless livestock production systems. In relation to Asian agriculture systems, three broad categories are identified [30]: i) Landless; ii) Cropbased; and iii) Rangeland-based. Classified in these ways, it is clear that livestock production systems differ in terms of their resource availability and use and the potential to adopt and use technologies that demand different resource inputs.

Facing the problem of a shortage of land on Java Island, and to meet the demand for meat production, various approaches to cattle production systems are required. Opportunities include:

i) Crop-livestock integrated system: This system is appropriate for Java Island due to the limited availability of land. An FAO report concluded there were benefits of restricted use of resource lands to mixed crop and livestock enterprises [31].

ii) Plantation-livestock integrated system: Integrated palm oil plantation and cattle systems have been the most practical systems in Indonesia and Malaysia over the past two decades.

Strategies needed for the utilization of low quality of feeds, mainly crop-by products in crop-livestock integrated systems are as follows:

i) Utilization appropriate and adoptable technologies to maintain feed availability, improve quality of feeds and to optimize nutritive value of the diet [16]. Fermented total mixed ration (TMR) as complete feed is a simple method to potentially improve nutrient utilization and extend the shelf life of the feed [32].

ii) Adoption of forage - legumes (which fix of $\mathrm{N}$ ) in mixed farming systems, can provide high quality of feed, enhance both the level and rate of nutrient cycling in the system, leading to increased soil fertility, improve animal nutrition and 
increase overall production and protect environment, especially where land resource is limited [33].

\section{CONCLUDING REMARKS}

Indonesia, with the 250 million of people is the fourth largest country in terms of population. Current average meat consumption of $2.72 \mathrm{~kg} /$ capita/yr is projected to reach $3.36 \mathrm{~kg} /$ capita/yr in 2024 due to steadily growing population, income, and animal protein consumption. The increasing demand for meat has not been matched by domestic beef production, the supply of which is less than $60 \%$ of the national demand for beef. The gap between beef supply and demand is increasing. Live cattle and frozen meat imports are a shortcut solution in the short-medium term. Government efforts for more than 15 years to develop domestic beef cattle production for Indonesian self-sufficiency are yet to realise the objective of selfsufficiency in meat production. Control of female breeding cattle which are slaughtered at excessive levels, breeding and reproductive technologies, feeding strategies, simple technology development, farmer empowerment, technology transfer, intensive feedlot systems, and integration of cattle farming system with palm oil plantations or other productive plants enterprises are among the issues that should be addressed as a priority to develop and improve domestic beef production in Indonesia.

\section{CONFLICT OF INTEREST}

We certify that there is no conflict of interest with any financial organization regarding the material discussed in the manuscript.

\section{ACKNOWLEDGMENTS}

The authors would like to thank Professor Takafumi Gotoh from Kagoshima University for constructive suggestion and guide.

\section{REFERENCES}

1. Delgado C, Rosegrant M, Steinfeld H, Ehui S, Courbuis C. Livestock to 2020: the next food revolution. Outlook on Agric 2001;30:27-9.

2. Widi TSM. Mapping the impact of crossbreeding in smallholder farming systems in Indonesia [PhD Thesis]. Wageningen, the Netherlands: Wageningen University; 2015.

3. Sullivan GM, Diwyanto K. A value chain assessment of the livestock sector in Indonesia. Washington, DC, USA: United States Agency for International Development; 2007.

4. Market snapshot of beef in Indonesia [internet]. North Sydney NSW, Australia: Meat and Livestock Australia; 2017 [cited
2018 Feb 20]. Available from: http://www.mla.com.au

5. Kementerian Pertanian. Livestock statistics. Jakarta, Indonesia: Kementrian Pertanian Republik Indonesia; 2017.

6. Agus A, Budisatria IGS, Ngadiyono N, et al. Road map of beef cattle industry in Indonesia. Yogyakarta, Indonesia: APFINDO and Faculty of Animal Science, Universitas Gadjah Mada; 2014.

7. Biro Pusat Statistik. Indonesian statistical data [internet]. Jakarta, Indonesia: Biro Pusat Statistik; 2015 [cited 2017 Nov 18]. Available from: https://www.bps.go.id

8. Moss J, Morley P, Baker D, Al Moadhen H, Downie R. Improving methods for estimating livestock production and productivity. University of New England; 2016 Technical Report Series No: GO-11-2016.

9. Monitoring system for prices of main needs. [internet]. Jakarta, Indonesia: Kementrian Perdagangan Republik Indonesia; 2017 [cited 2017 Nov 18]. Available from: https://ews.kemendag. go.id

10. Widi TSM. Livestock sharing arrangements in the Province of Yogyakarta special region; perspectives from different stakeholders [Master Thesis]. Wageningen, the Netherlands: Wageningen University; 2004.

11. Handayani S, Fariyanti A, Nurmalina R. Simulation analysis for prediction of beef meat self-sufficiency in Indonesia. Indonesia. J Sosiohumaniora 2016;18:61-70.

12.Djajanegara A, Diwyanto K. Development strategies for genetic evaluation of beef production in Indonesia. In: Proceedings of ACIAR Workshop 2001; 2001 July 23-28; Khon Kaen, Thailand: ACIAR; 2001. pp. 40-7.

13. Priyanti A, Hanifah VW, Mahendri IGAP, Cahyadi F, Cramb RA. Small-scale beef cattle production in East Java. In: Proceedings of the Australian Agricultural and Resource Economics Society Annual Conference 2012; 2012 Feb 7-10; Fremantle, Western Australia: AARES; 2012. pp. 1-22.

14. Anderson S. Animal genetic resources and sustainable livelihoods. Ecol Econ 2003;45:331-9.

15. Moll HAJ, Staal SJ, Ibrahim MNM. Smallholder dairy production and markets: a comparison of production systems in Zambia, Kenya and Sri Lanka. Agric Syst 2007;94:593-603.

16. Agus A. Ruminant nutrition: the role of agricultural by products in beef cattle production. In: Proceedings of International Seminar "Improving Tropical Animal production for Food Security" 2015; 2015 Nov 3-5; Kendari: Southeast Sulawesi, Indonesia; 2015. pp. 1-5.

17. Bakrie B, Hogan J, Liang JB, Tareque AMM, Upadhyay RC. Ruminant nutrition and production in the tropics and sub tropics. Canberra, Australia: Australian Centre for International Agricultural Research; 1996.

18. Minister of Agriculture launches a program of 'a cow has to be pregnant' (UPSUS SIWAB). [internet]. Jakarta, Indonesia: Directorate General of Livestock and Animal Health; 2016 [cited 2018 May]. Available from: http://www.pertanian. 
go.id/ap_posts/detil/672/2016/10/08/22/36/43/Mentan $\% 20$ Luncurkan\%20UPSUS\%20SIWAB\%20-Sapi\%20Indukan\%20 Wajib\%20Bunting-

19. Rusdiana S, Soeharsono. UPSUS SIWAB Program for increasing beef cattle population and economical value of livestock enterprise. Forum Penelitian Agro Ekonomi 2017;35:125-37.

20. Artificial Insemination for UPSUS SIWAB reached target of 92,27\% [internet]. Jakarta, Indonesia: Trobos; 2017 [cited 2018 May]. Available from: http://www.trobos.com/detailberita/2017/12/12/57/9623/target-ib-upsus-siwab-tercapai-9227

21. Bebe BO, Udo HMJ, Thorpe W. Development of smallholder dairy systems in the Kenya highlands. Outlook Agric 2002;31: 113-20.

22. Udo HMJ, Aklilu HA, Phong LT, et al. Impact of intensification of different types of livestock production in smallholder crop-livestock systems. Livest Sci 2011;139:22-9.

23. Devendra C, Leng RA. Feed resources for animals in Asia: issues, strategies for use, intensification and integration for increased productivity. Asian-Australas J Anim Sci 2011;24: 303-21.

24. Widi TSM, Yuwanta T, Agus A, Pertiwiningrum A. Roadmap for beef cattle development in Yogyakarta Province. Yogyakarta, Indonesia: Ardana Media; 2008.

25. Ilham N, Saliem HP. Financial feasibility of palm-oil plantation and cattle integrated system through credit scheme for cattle breeding. J Analisis Kebijakan Pertanian 2011;9:349-69.
26. Utomo BN, Widjaja E. Beef cattle development based on palm oil plantation industry. J Litbang Pert 2012;31:153-61.

27. Bijman J, Ton G, Meijerink G. Empowering smallholder farmers in markets: national and international policy initiatives. Wageningen, the Netherlands: Wageningen University and Research Centre; 2007.

28. De Haan C, Steinfeld H. Livestock and environment: finding a balance. FAO Report. Rome, Italy: Food and Agricultural Organization; 1996.

29. Sere C, Steinfeld H. World livestock production systems: current status, issues and trends. FAO Animal Production and Health Paper. Rome, Italy: Food and Agricultural Organization; 1995.

30.Devendra C. Perspectives on animal production systems in Asia. Livest Sci 2007;106:1-18.

31.FAO. Mixed crop-livestock farming: A review of traditional technologies based on literature and field experiences. FAO Animal Production and Health Paper. Vol. 152. Rome, Italy: Food and Agricultural Organization; 2001.

32. Wongnen C, Wachirapakorn C, Patipan D, et al. Effects of fermented total mixed ration and cracked cottonseed on milk yield and milk composition in dairy cows. Asian-Australas J Anim Sci 2009;22:1625-32.

33. Kebede G, Assefa G, Feyissa F, Mengistu A. Forages-legumes in crop-livestock mixed farming systems: a review. Int J Livest Res 2016;6:1-18. 